\title{
Two New Meroterpenoids, Penisimplicin A and B, Isolated from Penicillium simplicissimum
}

\author{
Shin-ichirou Komai, ${ }^{a}$ Tomoo Hosoe, ${ }^{a}$ Takeshi Itabashi, ${ }^{a}$ Koohei Nozana, ${ }^{a}$ Kaoru Okada,,${ }^{b}$ \\ Galba Maria de CAmpos TAKaKi, ${ }^{b}$ Takashi YAGUChI,${ }^{c}$ Kayoko TAKIZAwa, ${ }^{c}$ Kazutaka Fukushima, ${ }^{c}$ and \\ Ken-ichi KaWAI ${ }^{*, a}$ \\ ${ }^{a}$ Faculty of Pharmaceutical Sciences, Hoshi University; 2-4-41 Ebara, Shinagawa-ku, Tokyo 142-8501, Japan: ${ }^{b}$ Nucleo \\ de Pesquisas em Ciencias Ambientais, Universidade Catolica de Pernambuco; Rua Nunes Machado, 42-Boa Vista, Bl.J., \\ CEP 50050-200 Recife, PE, Brasil: and ${ }^{c}$ Research Center for Pathogenic Fungi and Microbial Toxicoses, Chiba \\ University; 1-8-1 Inohana, Chuo-ku, Chiba 260-8673, Japan. Received March 15, 2005; accepted May 12, 2005
}

In the course of our rsearch for new antifungal agents, two new meroterpenoids, penisimplicin A (1) and B (2), were isolated from Penicillium simplicissimum. The absolute structures of 1 and 2 were established by spectroscopic and chemical investigation. Penisimplicin A (1) and B (2) are rare examples of D-ring seco-meroterpenoids. Since compounds 1 and 2 showed no antifungal activities, the isolation of the compounds with antifungal activity will be attempted.

Key words Penicillium simplicissimum; meroterpenoid; penisimplicin A; penisimplicin B; andrastin A

The incidence of life-threatening fungal infections has steadily increased in immunocompromised hosts such as HIV infected persons and cancer patients. ${ }^{1)}$ Invasive pulmonary aspergillosis and Pneumocystis carinii pneumonia are the leading causes of death in bone marrow transplant recipients and in HIV-infected patients, respectively. Moreover, resistance to the azoles, which are the most widely used antifungals today, is attracting much attention. Therefore, novel antifungal agents are continuously required to treat and control the above fungal diseases.

During our screening for antifungal substances from 389 freshly isolated fungal strains in 1999, the chloroformmethanol $(1: 1)$ extracts of 166 strains $(34 \%)$ showed antifungal activity against two pathogenic filamentous fungi, $\mathrm{As}$ pergillus fumigatus FRESENIUS IFM 41243 and Aspergillus niger vaN TIEGHEM H7160B, and two pathogenic yeasts, Candida albicans (RoBIN) BERKHOUT IFM40009 and Cryptococcus neoformans (SANFelice) Vuillemin ATCC 90112. The extract of Penicillium simplicissimum (Oudemans) Tном strain IFM 53375 prompted us to isolate the antifungal active compounds. Instead of antifungal metabolites, two meroterpenoids, $\mathbf{1}$ and $\mathbf{2}$, designated as penisimplicin $\mathrm{A}$ and $\mathrm{B}$, respectively, were isolated from the dichloromethane-methanol $(1: 1)$ extract of this fungus. The structural elucidation of 1 and $\mathbf{2}$ are described in this paper.

The molecular formulae of penisimplicins A (1), colorless needles, $\mathrm{mp} 242-245^{\circ} \mathrm{C}$ (from benzene), and $\mathrm{B}$ (2), colorless needles, $\mathrm{mp} 252-254^{\circ} \mathrm{C}$ (from $\mathrm{MeOH}$ ), were confirmed as $\mathrm{C}_{30} \mathrm{H}_{40} \mathrm{O}_{10}$ and $\mathrm{C}_{28} \mathrm{H}_{38} \mathrm{O}_{8}$, respectively, by high resolution CI-MS and/or elemental analysis. These results assumed that penisimplicin B (2) may be a mono-deacetoxyl derivative of penisimplicin $\mathrm{A}(\mathbf{1})$.

From the analysis of the ${ }^{1} \mathrm{H}-\mathrm{NMR}$ spectrum (Table 1), it was clear that penisimplicin A (1) had six quaternary methyl groups [ $\delta 0.89(\mathrm{~s}), 1.10(\mathrm{~s}), 1.20(\mathrm{~s}), 1.37(\mathrm{~s}), 1.64(\mathrm{~s}), 1.67$ $(\mathrm{s})]$, two acetoxyl groups $[\delta 2.03(\mathrm{~s}), 2.04(\mathrm{~s})]$ and their attaching methine protons $[\delta 5.39$ (brdd), 4.71 (brd)], one methoxy group $[\delta 3.93(\mathrm{~s})]$, and one pair of exo-methylene protons $[\delta 4.95(\mathrm{brs}), 5.14(\mathrm{brs})]$. The ${ }^{13} \mathrm{C}$-NMR spectrum of 1 (Table 1) showed 30 carbons: they were assigned as 9 methyl carbons, one of which was assigned as a methoxy methyl carbon ( $\delta$ 53.6), $3 s p^{3}$ methylene carbons, $5 s p^{3}$ methine carbons, two of which were bearing an oxygen function

Table 1. ${ }^{1} \mathrm{H}$ - and ${ }^{13} \mathrm{C}-\mathrm{NMR}$ Chemical Shifts of Penisimplicins A (1) and B (2) in $\mathrm{CDCl}_{3}$

\begin{tabular}{|c|c|c|c|c|}
\hline \multirow{2}{*}{$\begin{array}{c}\text { Carbon } \\
\text { No. }\end{array}$} & \multicolumn{2}{|r|}{1} & \multicolumn{2}{|r|}{2} \\
\hline & $\delta_{\mathrm{C}}$ & $\delta_{\mathrm{H}}(J$ in $\mathrm{Hz})$ & $\delta_{\mathrm{C}}$ & $\delta_{\mathrm{H}}(J$ in $\mathrm{Hz})$ \\
\hline \multirow[t]{2}{*}{1} & 38.4 & 1.74 br dd $(13.6,9.9)$ & 36.8 & $1.51 \mathrm{~m}$ \\
\hline & & 1.92 ddd $(13.6,9.5,7.3)$ & & 1.95 ddd $(13.3,8.2,5.2)$ \\
\hline \multirow[t]{2}{*}{2} & 32.4 & 2.74 ddd $(15.0,9.9,7.3)$ & 33.4 & 2.48 ddd $(15.9,7.9,7.9)$ \\
\hline & & 2.34 ddd $(15.0,9.5,2.9)$ & & 2.55 ddd $(15.9,8.9,5.0)$ \\
\hline 3 & 216.2 & & 216.2 & \\
\hline 4 & 46.6 & & 46.7 & \\
\hline 5 & 53.8 & $2.21 \mathrm{brd}(11.3)$ & 51.5 & $1.63 \mathrm{~m}$ \\
\hline \multirow[t]{2}{*}{6} & 70.6 & 5.39 br dd $(11.3,9.7)$ & 26.4 & $1.53 \mathrm{~m}$ \\
\hline & & & & 1.80 br q (12.5) \\
\hline \multirow[t]{2}{*}{ 6-OAc } & 169.5 & & & \\
\hline & 21.4 & $2.03 \mathrm{~s}$ & & \\
\hline 7 & 82.1 & 4.71 brd $(9.7)$ & 80.4 & $4.68 \mathrm{dd}(11.3,4.3)$ \\
\hline \multirow[t]{2}{*}{ 7-OAc } & 171.4 & & 171.2 & \\
\hline & 21.0 & $2.04 \mathrm{~s}$ & 21.5 & $2.09 \mathrm{~s}$ \\
\hline 8 & 43.8 & & 43.5 & \\
\hline 9 & 57.7 & 1.11 brd (10.5) & 58.9 & $0.90 \mathrm{dd}(12.5,2.2)$ \\
\hline 10 & 37.6 & & 38.2 & \\
\hline \multirow[t]{2}{*}{11} & 28.6 & 2.21 br d (12.9) & 28.5 & $2.19 \mathrm{dd}(13.8,2.2)$ \\
\hline & & 2.41 br dd $(12.9,10.5)$ & & $2.40 \mathrm{dd}(13.8,12.5)$ \\
\hline 12 & 143.9 & & 144.5 & \\
\hline 13 & 51.4 & & 51.5 & \\
\hline 14 & 55.5 & $2.65 \mathrm{~s}$ & 56.0 & $2.60 \mathrm{~s}$ \\
\hline 15 & 166.8 & & 167.1 & \\
\hline 16 & 85.5 & & 85.5 & \\
\hline 17 & 201.4 & & 201.5 & \\
\hline 18 & 23.9 & $1.37 \mathrm{~s}$ & 23.9 & $1.39 \mathrm{~s}$ \\
\hline 19 & 18.1 & $0.89 \mathrm{~s}$ & 16.4 & $0.96 \mathrm{~s}$ \\
\hline 20 & 22.0 & $1.67 \mathrm{~s}$ & 22.0 & $1.67 \mathrm{~s}$ \\
\hline 21 & 168.5 & & 168.6 & \\
\hline 21-OMe & 53.6 & $3.93 \mathrm{~s}$ & 53.7 & 3.89 \\
\hline \multirow[t]{2}{*}{22} & 111.3 & $4.95 \mathrm{brs}$ & 110.9 & $4.91 \mathrm{brs}$ \\
\hline & & 5.14 br s & & 5.09 br s \\
\hline 23 & 13.6 & $1.64 \mathrm{~s}$ & 12.6 & $1.58 \mathrm{~s}$ \\
\hline 24 & 19.5 & $1.10 \mathrm{~s}$ & 20.6 & $1.05 \mathrm{~s}$ \\
\hline 25 & 31.0 & $1.20 \mathrm{~s}$ & 27.1 & $1.09 \mathrm{~s}$ \\
\hline
\end{tabular}


( $\delta 70.6,82.1), 5 s p^{3}$ quaternary carbons, one of which was bearing an oxygen function $(\delta 85.5)$, one $s p^{2}$ methylene carbon and one $s p^{2}$ quaternary carbons $(\delta 111.3,143.9$, respectively), four ester carbonyl carbons ( $\delta$ 166.8, 168.5, 169.5, $171.4)$ and two ketone carbons $(\delta$ 201.4, 216.2). From the above results, it was assumed that $\mathbf{1}$ must be a tetracyclic terpenoid. Detailed analyses of the ${ }^{1} \mathrm{H}-{ }^{1} \mathrm{H}$ COSY, HMQC, and HMBC (Fig. 1) spectra confirmed the planar structure of penisimplicin A (1).

The relative stereochemistriy of penisimplicin A (1) was confirmed from analysis of the NOESY spectrum. Nuclear Overhauser enhancement (NOE) correlations were observed between one of the methyl protons at C-4 $(\delta 1.10)$ and the methyl protons at $\mathrm{C}-10(\delta 0.89)$, the methyl protons at $\mathrm{C}-10$ and the methyl protons at C-8 $(\delta 1.64)$, and the methyl protons at $\mathrm{C}-8$ and the methyl protons at $\mathrm{C}-13(\delta 1.37)$. On the other hand, NOE correlations were observed between the other methyl protons at C-4 $(\delta 1.20)$ and one of the protons at $\mathrm{C}-2(\delta 2.74)$, the above proton and $5-\mathrm{H}(\delta 2.21), 5-\mathrm{H}$ and $9-\mathrm{H}(\delta 1.11)$, and $9-\mathrm{H}$ and $14-\mathrm{H}(\delta 2.65)$. These results indicated that three methyl groups at C-8, C-10 and C-13 were on the same side as one of the methyl groups at $\mathrm{C}-4$, whereas three protons at C-5, C-9, and C-14 were on the same side as

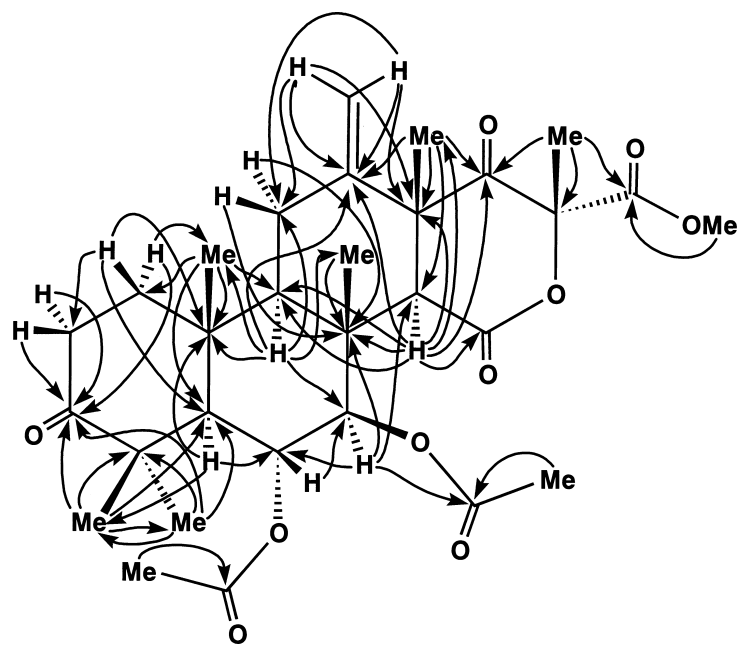

the other methyl groups at C-4. Therefore, it is clear that all four rings fused in an anti-trans configuration. NOE correlations were observed between the methyl protons at $\mathrm{C}-10$ and $6-\mathrm{H}(\delta 5.39)$, and between $5-\mathrm{H}$ and 7-H ( $\delta 4.71)$. Therefore, it was confirmed that the 6-acetoxyl group had the opposite orientation as the methyl group at $\mathrm{C}$-10, whereas the 7-acetoxyl group had the same orientation as the methyl group at $\mathrm{C}-10$. The configuration at $\mathrm{C}-16$ could not be determined from the analysis of the NOESY spectrum of 1 .

The reduction of penisimplicin A (1) with $\mathrm{NaBH}_{4}$ gave compound $\mathbf{3}$. The molecular formula of $\mathbf{3}$ was confirmed as $\mathrm{C}_{30} \mathrm{H}_{44} \mathrm{O}_{10}$, which indicated that $\mathbf{3}$ was the tetrahydro derivative of 1 . The ${ }^{1} \mathrm{H}$ - and ${ }^{13} \mathrm{C}$-NMR signals of $\mathbf{3}$ were similar to those of 1 , except for the appearance of two protons $[\delta 3.18$ $(1 \mathrm{H}$, ddd, $J=12.5,11.3,6.0 \mathrm{~Hz}), 4.83(1 \mathrm{H}, \mathrm{d}, J=6.7 \mathrm{~Hz})]$ attached to the carbons bearing the hydroxyl group $(\delta 77.8$, 75.8 , respectively) in 3 instead of two ketones $\left(\delta_{\mathrm{C}} 216.2\right.$, 201.4 ) in 1. This result and detailed analysis of the ${ }^{1} \mathrm{H}-{ }^{1} \mathrm{H}$ COSY, HMQC, HMBC and NOESY spectra showed that $\mathbf{3}$ should be 3,17-bisdeoxo-3,17-dihydroxy derivative of $\mathbf{1}$. The stereochemistry of the methyl group at C-16 in 3 was determined to be the same orientation as the methyl group at $\mathrm{C}-13$, since a NOE of $1.9 \%$ was observed on the methyl protons at $\mathrm{C}-13(\delta 1.17)$ when the methyl protons at C-16 $(\delta 1.55)$ were irradiated in the difference nuclear Overhauser enhancement (NOE) experiment. The stereochemistry of the hydroxyl group at C-3 was determined from the NOE correlation between $3-\mathrm{H}(\delta 3.18)$ and $5-\mathrm{H}(\delta 1.31)$, whereas that of the hydroxyl at $\mathrm{C}-17$ was determined from the NOE correlation between 14-H $(\delta 1.85)$ and $17-\mathrm{H}(\delta 4.83)$, in the NOESY spectrum of 3 . Since the relative structure of 3,17-bisdeoxo-3,17dihydroxypenisimplicin A (3) was determined, the relative structure of penisimplicin A was confirmed as shown in $\mathbf{1}$.

In order to determine the absolute configuration by the exiton chirality method, penisimplicin A (1) was solvolysed with $\mathrm{KOH}$ in $\mathrm{MeOH}$ to give a degraded compound 4, mp $219-220^{\circ} \mathrm{C}$ (from EtOH), $\mathrm{C}_{24} \mathrm{H}_{36} \mathrm{O}_{7}$. Compound 4 showed the presence of hydroxyl group $(\mathrm{s})\left(3570 \mathrm{~cm}^{-1}\right)$, ester(s) $\left(1750 \mathrm{~cm}^{-1}\right)$, and ketone(s) $\left(1700 \mathrm{~cm}^{-1}\right)$ in the IR spectrum. From the analysis of the ${ }^{1} \mathrm{H}-\mathrm{NMR}$ spectrum of 4 , it was clear that 4 had five quaternary methyl groups $[\delta 0.84(\mathrm{~s}), 1.30(\mathrm{~s})$,

Fig. 1. HMBC Correlations in Penisimplicin A (1)
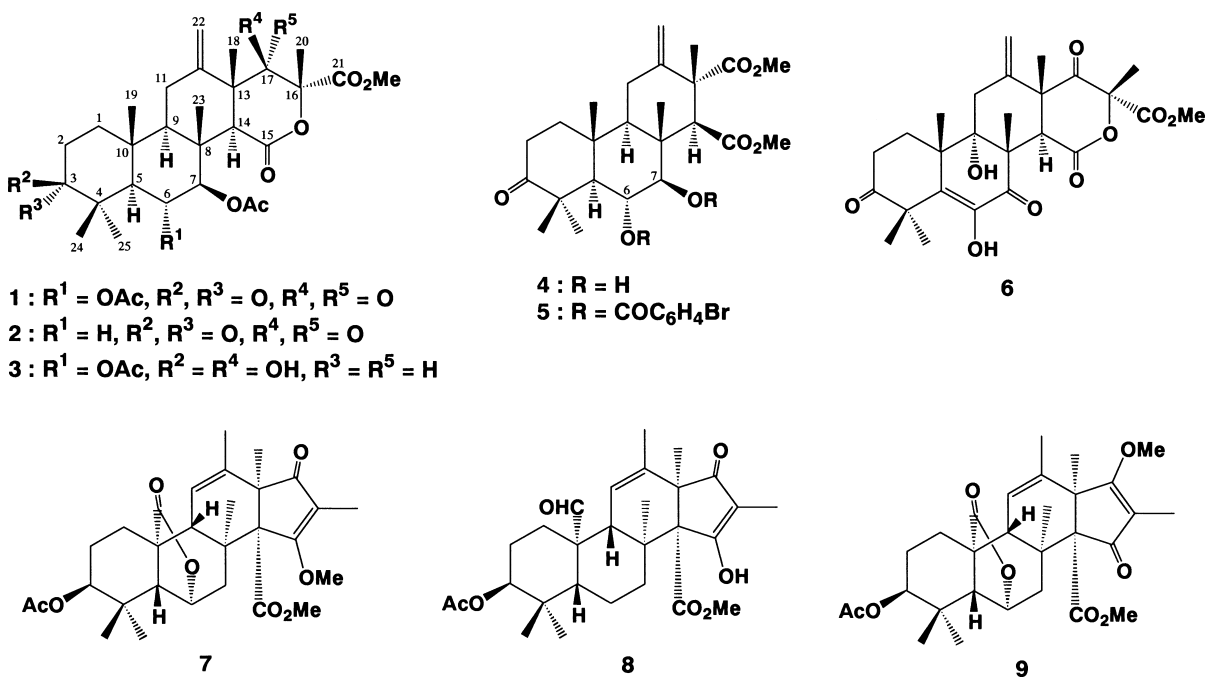

Chart 1 
$1.32(\mathrm{~s}), 1.33(\mathrm{~s}), 1.54(\mathrm{~s})]$, two methoxy groups [ $\delta 3.64(\mathrm{~s})$, $3.72(\mathrm{~s})]$, two $s p^{3}$ methine protons $[\delta 3.70(\mathrm{~m}), 3.37(\mathrm{~d})]$ attached to the carbons bearing hydroxyl groups], and one pair of exo-methylene protons [ $\delta 4.95$ (br s), 5.14 (br s)]. The ${ }^{13} \mathrm{C}$ NMR spectrum of 4 showed 24 carbons: they were assigned as 7 methyl carbons, two of which were assigned as methoxy methyl carbons $(\delta 53.3,59.3), 3 s p^{3}$ methylene carbons, $5 s p^{3}$ methine carbons, two of which were bearing an oxygen function $(\delta 70.4,84.7), 4 s p^{3}$ quaternary carbons, one $s p^{2}$ methylene carbon and one $s p^{2}$ quaternary carbon $(\delta 109.4,148.8$, respectively), two ester carbonyl carbons ( $\delta$ 173.7, 175.3), and one ketone carbon ( $\delta$ 218.3). From the above results, analysis of the ${ }^{1} \mathrm{H}-{ }^{1} \mathrm{H}$ COSY, HMQC, and HMBC spectra and the structural correlation to penisimplicin A (1), the relative structure of $\mathbf{4}$ was confirmed. Benzoylation of $\mathbf{4}$ with an excess of $p$-bromobenzoyl chloride gave 6,7-di- $p$-bromobenzoate of 4 (5).

The absolute stereochemistry of penisimplicin A (1) was confirmed by the exciton chirality method using di- $p$-bromobenzoate (5). ${ }^{2)}$ The CD spectra of 5 exhibited strong negative first $[\Delta \varepsilon-16.4(254 \mathrm{~nm})]$ and positive second $[\Delta \varepsilon$ $+12.4(237 \mathrm{~nm})]$ Cotton effects. These were due to the coupling between the intramolecular CT transitions of two benzoate chromophores, and this phenomenon showed that two benzoate moieties in $\mathbf{5}$ were twisted in a counter-clockwise manner. Thus, the chirality of C-6 and C-7 of 5 was found to be $6 R, 7 R$. The absolute configuration of penisimplicin $\mathrm{A}(\mathbf{1})$ was consequently confirmed as $6 R, 7 R$.

The ${ }^{1} \mathrm{H}$ - and ${ }^{13} \mathrm{C}-\mathrm{NMR}$ signals of penisimplicin $\mathrm{B}$ (2) (Table 1) were similar to those of co-occurring 1, except for the disappearance of one acetoxyl group $\left[\delta_{\mathrm{H}} 2.03(3 \mathrm{H}, \mathrm{s}), \delta_{\mathrm{C}}\right.$ 169.5] and the appearance of methylene protons $[\delta 1.53(1 \mathrm{H}$, $\mathrm{m}), 1.80(1 \mathrm{H}$, br q, $J=12.5 \mathrm{~Hz})]$ attached to the carbon $(\delta$ $26.4)$ instead of the proton $[\delta 5.39(1 \mathrm{H}$, brdd, $J=11.3$, $9.7 \mathrm{~Hz})$ ] attached to the carbon bearing the acetoxyl group ( $\delta$ 70.6). The only other differences observed in the ${ }^{13} \mathrm{C}$-NMR spectra of $\mathbf{1}$ and $\mathbf{2}$ were as follows: the signals observed at $\delta$ 38.4 (C-1), 32.4 (C-2), 53.8 (C-5), 82.1 (C-7), 57.7 (C-9), 18.1 (C-19), 13.6 (C-23), 19.5 (C-24), and $31.0(\mathrm{C}-25)$ in 1 were shifted to $36.8(\mathrm{C}-1), \delta 33.4(\mathrm{C}-2), 51.5(\mathrm{C}-5), 80.4(\mathrm{C}-$ 7), 58.9 (C-9), 16.4 (C-19), 12.6 (C-23), 20.6 (C-24), and $27.1(\mathrm{C}-25)$ in 2 , respectively. From the above results and analysis of the ${ }^{1} \mathrm{H}-{ }^{1} \mathrm{H}$ COSY, HMQC, and HMBC (Fig. 2) spectra, the planar structure of penisimplicin B (2) was confirmed to be the 6-deacetoxyl derivative of penisimplicin A (1). The relative stereochemistry of penisimplicin B (2) was confirmed from analysis of the NOESY spectra (Fig. 3), except for the stereochemistry at C-16. The absolute stereochemistry of penisimplicin B (2) was assumed to be the same as that of penisimplicin A (1), since the CD curves of $\mathbf{1}$ and $\mathbf{2}$ $[\Delta \varepsilon-3.8(230),-4.2(295 \mathrm{~nm})$ for $1 ; \Delta \varepsilon-3.3(229),-5.0$ $(301 \mathrm{~nm})]$ were almost superimposable.

Penisimplicin A (1) and B (2) should be meroterpenoids, which would be biosynthesized through a mixed polyketideterpenoid pathway. ${ }^{3,4)}$ In 1979, terretonin (6) was isolated as mycotoxin from Aspergillus terreus Tном. ${ }^{5)}$ Recently, citreoviridone A and B (7) were isolated from a hybrid strain derived from two strains of Penicillium citreo-viride Biourge, ${ }^{6}$ and androstin $\mathrm{A}(\mathbf{8}), \mathrm{B}$, and $\mathrm{C}$ were isolated as protein farnesyltransferase inhibitors from Penicillium sp. ${ }^{7)}$ Penisimplicin A (1) and B (2) are rare examples of D-ring seco-meroter-

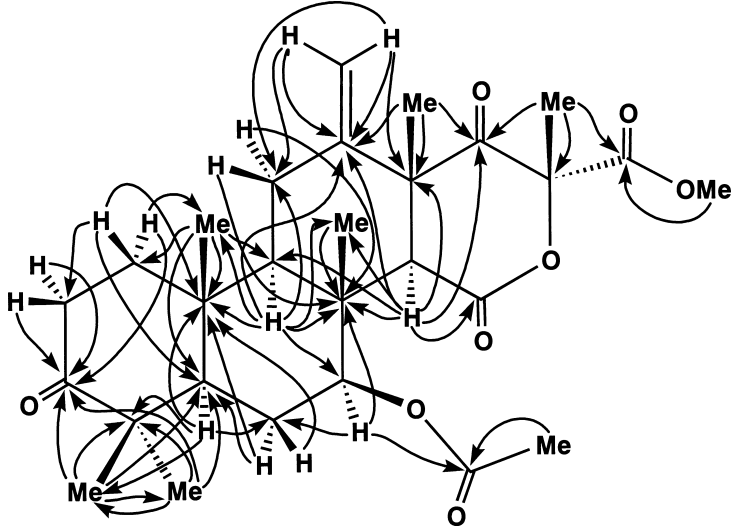

Fig. 2. HMBC Correlations in Penisimplicin B (2)

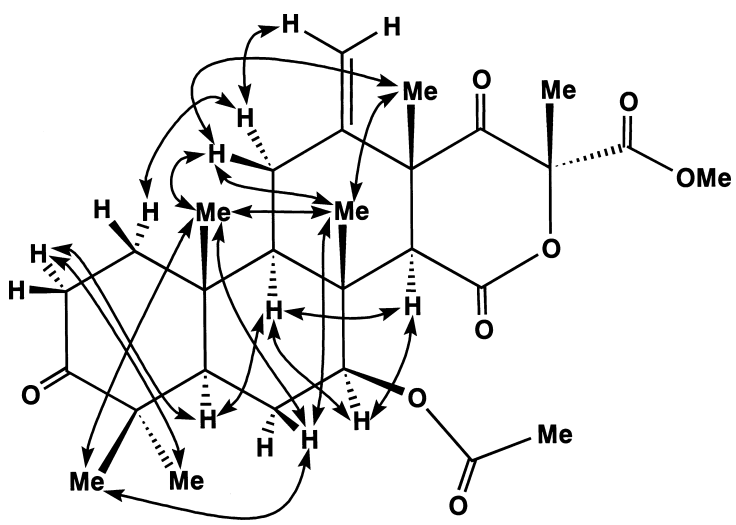

Fig. 3. NOE Correlations in the NOESY Spectrum of Penisimplicin B (2)

penoids, such as terretonin (6) ${ }^{5}$ )

The absolute configuration of meroterpenoids was first confirmed in androstin A (8) by X-ray analysis of the $p$-bromobenzoate of $\mathbf{8}^{8)}$ The absolute configuration of citreohybridones was determined using the modified Mosher method applied to the MTPA ester of isocitreohybridone C (9). ${ }^{9}$ Their skeletons were shown to be ent-5 $\alpha, 14 \beta$-androstane, the enantiomer of the normal androstane. On the other hand, penisimplicin A (1) and B (2) had the same absolute configuration of the normal $5 \alpha, 14 \beta$-androstane.

\section{Experimental}

Melting points were determined on a Yanagimoto micro-melting point apparatus and are uncorrected. Optical rotations were measured on a JASCO DIP-1000 photopolarimeter. EI-MS was taken with a JEOL JMS-MS600W spectrometer. The ultraviolet (UV) and infrared (IR) spectra were recorded on a Hitachi U-3210 spectrophotometer and a JASCO IR-810 spectrophotometer, respectively. ${ }^{1} \mathrm{H}$ - and ${ }^{13} \mathrm{C}-\mathrm{NMR}$ spectra were recorded on a JEOL Lambda-500 $\left({ }^{1} \mathrm{H}, \quad 500.00 \mathrm{MHz} ;{ }^{13} \mathrm{C}, \quad 125.43 \mathrm{MHz}\right)$ spectrometer, using tetramethylsilane as an internal standard. $\mathrm{CD}$ curves were determined on a JASCO J-600 spectropolarimeter. Column chromatography was performed using Kieselgel 60 (Art. 7734, Merck). Low-pressure liquid chromatography (LPLC) was performed with a SEC SS50-1296 pump and glass column $(300 \times 20 \mathrm{~mm})$ packed with Silica gel CQ-3 $(30-50 \mu \mathrm{m}$, Wako). HPLC was performed with a Senshu SSC-3160 pump (flow rate, $4 \mathrm{ml} / \mathrm{min}$ ), equipped with a Shimamura YRD-883 RI detector. TLC was conducted on pre-coated Kieselgel $60 \mathrm{~F}_{254}$ plates (Art. 5715; Merck). Spots on TLC were detected by UV light at $254 \mathrm{~nm}$ and/or by spraying with a phosphomolybdate reagent and then heating.

Isolation of Penisimplicin A (1) and B (2) $P$. simplicissimum IFM 53375 was cultured at $25^{\circ} \mathrm{C}$ for $21 \mathrm{~d}$ in 20 Roux flasks containing $150 \mathrm{~g}$ of moist rice in each flask. The cultivated rice was extracted with $\mathrm{CH}_{2} \mathrm{Cl}_{2}-\mathrm{MeOH}(1: 1)$ and the organic layer was evaporated in vacuo. After 
the partition with AcOEt- $\mathrm{H}_{2} \mathrm{O}$, the evaporated residue of the organic layer (40 g) was chromatographed on silica gel in sequence with $\mathrm{CH}_{2} \mathrm{Cl}_{2}-\mathrm{EtOH}$ (50:1), $\mathrm{CH}_{2} \mathrm{Cl}_{2}-\mathrm{EtOH}(20: 1)$, and $\mathrm{CH}_{2} \mathrm{Cl}_{2}-\mathrm{EtOH}(10: 1)$. The residue eluted with $\mathrm{CH}_{2} \mathrm{Cl}_{2}-\mathrm{EtOH}(20: 1)$ was purified with LPLC on silica gel using a benzene-acetone $(15: 1)$ solvent system followed by purification with HPLC on silica gel [benzene-acetone $(10: 1)$ ] to give penisimplicin A (1) $(1.0 \mathrm{~g})$. The less polar fraction of the LPLC eluate was purified with HPLC on silica gel [hexane-AcOEt $(3: 1)$ ] to give penisimplicin B (2) (70 mg).

Penisimplicin A (1): Colorless needles, $\mathrm{mp} 242-245^{\circ} \mathrm{C}$ (from benzene) $[\alpha]_{\mathrm{D}}^{20}-298^{\circ}\left(c=0.1, \mathrm{CHCl}_{3}\right)$. Anal. Calcd for $\mathrm{C}_{30} \mathrm{H}_{40} \mathrm{O}_{10}: \mathrm{C}, 64.27 ; \mathrm{H}, 7.19$. Found: C, 64.11; H, 7.08. EI-MS m/z (\%): $560\left(\mathrm{M}^{+}, 6\right), 500(\mathrm{M}-\mathrm{AcOH}$, 38), 457 (100), 440 (62), 342 (42), 327 (31), 309 (34), 300 (100), 282 (43), 267 (27). CI-MS (isobutane) $\mathrm{m} / \mathrm{z}(\%): 561.2703\left[(\mathrm{M}+\mathrm{H})^{+}, 561.2699\right.$ for $\left.\mathrm{C}_{30} \mathrm{H}_{41} \mathrm{O}_{10}, 33\right], 501(\mathrm{M}+\mathrm{H}-\mathrm{AcOH}, 100)$. UV $\lambda_{\max }^{\mathrm{MeOH}}$ end absorption. IR $v_{\max }^{\mathrm{KBr}} \mathrm{cm}^{-1}: 1745$ (-COO-), $1710(-\mathrm{CO}-) . \mathrm{CD}(\mathrm{MeOH}) \Delta \varepsilon(\mathrm{nm}):-3.8$ (230), -4.2 (295). The ${ }^{1} \mathrm{H}$ - and ${ }^{13} \mathrm{C}-\mathrm{NMR}$ signal assignments are summarized in Table 1.

Penisimplicin B (2): Colorless needles, mp 252-254 ${ }^{\circ} \mathrm{C}$ (from $\left.\mathrm{MeOH}\right)$. $[\alpha]_{\mathrm{D}}^{20}-118^{\circ}\left(c=0.11, \mathrm{CHCl}_{3}\right)$. EI-MS $m / z \quad(\%): 502\left(\mathrm{M}^{+}, 8\right), 442$ (M-AcOH, 80), 311 (33), 284 (100). CI-MS (isobutene) $\mathrm{m} / \mathrm{z}$ (\%): 503.2639 $\left[(\mathrm{M}+\mathrm{H})^{+}, 503.2645\right.$ for $\left.\mathrm{C}_{28} \mathrm{H}_{39} \mathrm{O}_{8}, 70\right], 443(\mathrm{M}+\mathrm{H}-\mathrm{AcOH}, 100)$. UV $\lambda_{\max }^{\mathrm{MeOH}}$ end absorption. IR $v_{\max }^{\mathrm{KBr}} \mathrm{cm}^{-1}: 1730$ (-COO-), 1705 (-CO-). CD (MeOH) $\Delta \varepsilon(\mathrm{nm}):-3.3(229),-5.0(301)$. The ${ }^{1} \mathrm{H}-$ and ${ }^{13} \mathrm{C}-\mathrm{NMR}$ signal assignments are summarized in Table 1 .

Reduction of Penisimplicin A (1) by $\mathbf{N a B H}_{4} \quad \mathrm{NaBH}_{4}(30 \mathrm{mg})$ was added to a $\mathrm{MeOH}$ solution $(6 \mathrm{ml})$ of penisimplicin $\mathrm{A}(\mathbf{1})(100 \mathrm{mg})$ and the mixture was stirred at $0^{\circ} \mathrm{C}$ for $30 \mathrm{~min}$. The reaction mixture was acidified with $4 \mathrm{M} \mathrm{HCl}$ and extracted with $\mathrm{CH}_{2} \mathrm{Cl}_{2}$. The evaporated residue was purified with HPLC on silica gel $\left[\mathrm{CH}_{2} \mathrm{Cl}_{2}\right.$-acetone $\left.(5: 1)\right]$ to give 3,17-bisdeoxo3,17-dihydroxypenisimplicin A (3) (35 mg).

3,17-Bisdeoxo-3,17-dihydroxypenisimplicin A (3): Colorless microcrystalline powder, $\mathrm{mp} 185-187^{\circ} \mathrm{C}$ (from benzene). $[\alpha]_{\mathrm{D}}^{20}-298^{\circ}(c=0.11$, $\mathrm{CHCl}_{3}$ ). EI-MS $m / z$ (\%): $564\left(\mathrm{M}^{+}, 21\right), 444$ (63), 311 (33), 244 (100). CIMS (isobutene) $m / z(\%): 565.3011\left[(\mathrm{M}+\mathrm{H})^{+}, 565.3012\right.$ for $\left.\mathrm{C}_{30} \mathrm{H}_{45} \mathrm{O}_{10}, 38\right]$. UV $\lambda_{\max }^{\mathrm{MeOH}}$ end absorption. IR $v_{\max }^{\mathrm{KBr}} \mathrm{cm}^{-1}: 3400(\mathrm{OH}), 1750(-\mathrm{COO}-)$. CD $(\mathrm{MeOH}) \Delta \varepsilon(\mathrm{nm}):-5.1(225),-4.2(295) .{ }^{1} \mathrm{H}-\mathrm{NMR}\left(\mathrm{CDCl}_{3}\right) \delta: 0.86(3 \mathrm{H}$, s, $\left.24-\mathrm{H}_{3}\right), 0.90(1 \mathrm{H}, \mathrm{brd}, J=11.0 \mathrm{~Hz}), 1.03\left(3 \mathrm{H}, \mathrm{s}, 19-\mathrm{H}_{3}\right), 1.05(1 \mathrm{H}, \mathrm{m}, 1-$ $\mathrm{H}), 1.06\left(3 \mathrm{H}, \mathrm{s}, 25-\mathrm{H}_{3}\right), 1.17\left(3 \mathrm{H}, \mathrm{s}, 18-\mathrm{H}_{3}\right), 1.31(1 \mathrm{H}, \mathrm{d}, J=11.6 \mathrm{~Hz}, 5 \alpha-\mathrm{H})$, $1.38(1 \mathrm{H}, \mathrm{d}, J=6.0 \mathrm{~Hz}, 3-\mathrm{OH}), 1.55\left(3 \mathrm{H}, \mathrm{s}, 20-\mathrm{H}_{3}\right), 1.60(1 \mathrm{H}, \mathrm{m}, 2-\mathrm{H}), 1.64$ $\left(3 \mathrm{H}, \mathrm{s}, 23-\mathrm{H}_{3}\right), 1.73(1 \mathrm{H}, \mathrm{m}), 1.83(1 \mathrm{H}, \mathrm{ddd}, J=13.1,13.1,3.4 \mathrm{~Hz}, 1-\mathrm{H})$, $1.85(1 \mathrm{H}, \mathrm{s}, 14 \beta-\mathrm{H}), 1.99(3 \mathrm{H}, \mathrm{s}, 6-\mathrm{OAc}), 2.02(3 \mathrm{H}, \mathrm{s}, 7-\mathrm{OAc}), 2.07(1 \mathrm{H}, \mathrm{d}$, $J=6.7 \mathrm{~Hz}, 17-\mathrm{OH}), 2.22(1 \mathrm{H}, \mathrm{brd}, J=12.8 \mathrm{~Hz}, 11-\mathrm{H}), 2.32(1 \mathrm{H}, \mathrm{dd}, J=12.8$, $11.0 \mathrm{~Hz}, 11-\mathrm{H}), 3.18(1 \mathrm{H}, \mathrm{ddd}, J=12.5,11.3,6.0 \mathrm{~Hz}, 3 \alpha-\mathrm{H}), 3.90(3 \mathrm{H}, \mathrm{s}, 21-$ OMe), $4.59(1 \mathrm{H}, \mathrm{d}, J=9.2 \mathrm{~Hz}, 7 \beta-\mathrm{H}), 4.83(1 \mathrm{H}, \mathrm{d}, J=6.7 \mathrm{~Hz}, 17 \alpha-\mathrm{H}), 4.84$ $(1 \mathrm{H}$, br s, $22-\mathrm{H}), 5.10(1 \mathrm{H}$, br s, $22-\mathrm{H}), 5.48(1 \mathrm{H}, \mathrm{dd}, J=11.6,9.2 \mathrm{~Hz}, 6 \alpha-\mathrm{H})$. ${ }^{13} \mathrm{C}-\mathrm{NMR}\left(\mathrm{CDCl}_{3}\right) \delta: 13.9$ (C-13), 15.5 (C-24), 17.3 (C-19), 18.2 (C-18), 21.2 (7-OAc), 21.7 (6-OAc), 22.5 (C-20), 26.6 (C-2), 28.3 (C-11), 29.7 (C25), 37.6 (C-1), 38.8 (C-4), 38.9 (C-10), 44.1 (C-8), 45.7 (C-13), 53.9 (21OMe), 55.6 (C-5), 56.8 (C-14), 57.1 (C-9), 70.3 (C-6), 75.8 (C-17), 77.8 (C3), 82.9 (C-7), 83.4 (C-16), 109.0 (C-22), 152.7 (C-12), 168.5 (C-15), 170.1 (6-OAc), 170.9 (7-OAc), 174.2 (C-21).

Methanolysis of Penisimplicin A (1) by KOH Penisimplicin A (1) $(200 \mathrm{mg})$ and $\mathrm{KOH}(300 \mathrm{mg})$ were dissolved in $\mathrm{MeOH}(5 \mathrm{ml})$ and the mixture was kept at $60^{\circ} \mathrm{C}$ for $16 \mathrm{~h}$. After adding $\mathrm{H}_{2} \mathrm{O}$, the reaction mixture was extracted with AcOEt. The AcOEt layer was methylated with $\mathrm{CH}_{2} \mathrm{~N}_{2}$ and evaporated in vacuo. The residue was purified with HPLC on silica gel $\left[\mathrm{CH}_{2} \mathrm{Cl}_{2}\right.$-acetone $\left.(7: 1)\right]$ to give $4(47 \mathrm{mg})$.

Compound 4: Colorless cubic, $\mathrm{mp} 219-220^{\circ} \mathrm{C}$ (from EtOH). $[\alpha]_{\mathrm{D}}^{20}$ $-157^{\circ}\left(c=0.175, \mathrm{CHCl}_{3}\right)$. EI-MS $m / z(\%)$ : $436.2469\left(\mathrm{M}^{+}, 436.2461\right.$ for
$\left.\mathrm{C}_{24} \mathrm{H}_{36} \mathrm{O}_{7}, 40\right), 404$ (100). CI-MS (isobutene) $\mathrm{m} / z(\%): 437\left[(\mathrm{M}+\mathrm{H})^{+}, 100\right]$. UV $\lambda_{\max }^{\mathrm{MeOH}}$ end absorption. IR $v_{\max }^{\mathrm{KBr}} \mathrm{cm}^{-1}: 3570(\mathrm{OH}), 1750(-\mathrm{COO}-), 1700$ $(-\mathrm{CO}-)$. CD (MeOH) $\Delta \varepsilon(\mathrm{nm}):+3.3(220),-3.3(290) .{ }^{1} \mathrm{H}-\mathrm{NMR}\left(\mathrm{CDCl}_{3}\right)$ $\delta: 0.84\left(3 \mathrm{H}, \mathrm{s}, 19-\mathrm{H}_{3}\right), 1.26(1 \mathrm{H}, \mathrm{dd}, J=13.2,3.0 \mathrm{~Hz}, 9 \beta-\mathrm{H}), 1.30(3 \mathrm{H}, \mathrm{s}, 24-$ $\left.\mathrm{H}_{3}\right), 1.32\left(3 \mathrm{H}, \mathrm{s}, 23-\mathrm{H}_{3}\right), 1.33\left(3 \mathrm{H}, \mathrm{s}, 25-\mathrm{H}_{3}\right), 1.54\left(3 \mathrm{H}, \mathrm{s}, 18-\mathrm{H}_{3}\right), 1.63(1 \mathrm{H}$, br s, OH), $1.70(1 \mathrm{H}$, ddd, $J=13.0,12.0,3.0 \mathrm{~Hz}, 1-\mathrm{H}), 1.85(1 \mathrm{H}, \mathrm{ddd}, J=13.0$, $10.0,7.0 \mathrm{~Hz}, 1-\mathrm{H}), 1.88(1 \mathrm{H}, \mathrm{d}, J=13.2 \mathrm{~Hz}, 5 \alpha-\mathrm{H}), 2.21(1 \mathrm{H}, \mathrm{dd}, J=13.1$, $3.0 \mathrm{~Hz}, 11-\mathrm{H}), 2.29(1 \mathrm{H}$, ddd, $J=15.2,10.0,3.0 \mathrm{~Hz}, 2-\mathrm{H}), 2.43(1 \mathrm{H}, \mathrm{dd}$, $J=13.2,13.1 \mathrm{~Hz}, 11-\mathrm{H}), 2.59(1 \mathrm{H}, \mathrm{s}, \mathrm{OH}), 2.74(1 \mathrm{H}, \mathrm{ddd}, J=15.2,12.0$, $7.0 \mathrm{~Hz}, 2-\mathrm{H}), 3.10(1 \mathrm{H}, \mathrm{s}, 14 \beta-\mathrm{H}), 3.37(1 \mathrm{H}, \mathrm{d}, J=8.9 \mathrm{~Hz}, 7 \beta-\mathrm{H}), 3.64(3 \mathrm{H}$, s, $15-\mathrm{OMe}), 3.70(1 \mathrm{H}, \mathrm{m}, 6 \alpha-\mathrm{H}), 3.72(3 \mathrm{H}, \mathrm{s}, 17-\mathrm{OMe}), 4.49(1 \mathrm{H}, \mathrm{br} \mathrm{s}, 22-$ $\mathrm{H}), 4.80(1 \mathrm{H}, \mathrm{br} \mathrm{s}, 22-\mathrm{H}),{ }^{13} \mathrm{C}-\mathrm{NMR}\left(\mathrm{CDCl}_{3}\right) \delta: 12.9(\mathrm{C}-23), 17.4(\mathrm{C}-19)$, 19.3 (C-24), 21.0 (C-18), 28.4 (C-11), 31.3 (C-25), 32.6 (C-2), 37.4 (C-10), 38.3 (C-1), 43.5 (C-8), 47.0 (C-4), 51.9 (15-OMe), 52.3 (17-OMe), 53.3 (C13), 55.0 (C-5), 55.4 (C-9), 59.3 (C-14), 70.4 (C-6), 84.7 (C-7), 109.4 (C22), 148.8 (C-12), 173.7 (C-15), 175.3 (C-17), 218.3 (C-3).

p-Bromobenzoylation of Compound 4 Compound $4(30 \mathrm{mg})$ and $p$ bromobenzoyl chloride $(1 \mathrm{~g})$ were dissolved in pyridine $(5 \mathrm{ml})$ and the mixture was kept at $120^{\circ} \mathrm{C}$ for $20 \mathrm{~h}$. The reaction mixture was dissolved in AcOEt and washed with $1 \mathrm{M} \mathrm{HCl}$ and then with $1 \mathrm{~m} \mathrm{NaHCO}$. The AcOEt layer was methylated with $\mathrm{CH}_{2} \mathrm{~N}_{2}$ and evaporated in vacuo. The residue was purified with HPLC on silica gel [benzene-AcOEt $(9: 1)$ ] to give di-p-bromobenzoate (5) (2 mg).

Di-p-bromobenzoate of 4 (5): EI-MS $m / z(\%): 802\left(\mathrm{M}^{+}, 10\right), 369$ (63), 185 (96), 105 (100). CI-MS (isobutene) $\mathrm{m} / \mathrm{z}(\%): 803.1227\left[(\mathrm{M}+\mathrm{H})^{+}\right.$, 803.1253 for $\left.\mathrm{C}_{38} \mathrm{H}_{43} \mathrm{O}_{9} \mathrm{Br}_{2}, 2\right]$. $\mathrm{CD}(\mathrm{MeOH}) \Delta \varepsilon(\mathrm{nm}):+12.4(237),-16.4$ (254). ${ }^{1} \mathrm{H}-\mathrm{NMR}\left(\mathrm{CDCl}_{3}\right) \delta: 0.92(3 \mathrm{H}, \mathrm{s}, \mathrm{Me}), 1.14(3 \mathrm{H}, \mathrm{s}, \mathrm{Me}), 1.19(3 \mathrm{H}, \mathrm{s}$, $\mathrm{Me}), 1.23(3 \mathrm{H}, \mathrm{s}, \mathrm{Me}), 1.43(3 \mathrm{H}, \mathrm{s}, \mathrm{Me}), 1.76(1 \mathrm{H}, \mathrm{d}, J=9.6 \mathrm{~Hz}), 3.03(1 \mathrm{H}$, $\mathrm{s}, 14-\mathrm{H}), 3.46\left(3 \mathrm{H}, \mathrm{s},-\mathrm{CO}_{2} \mathrm{Me}\right), 3.65\left(3 \mathrm{H}, \mathrm{s},-\mathrm{CO}_{2} \mathrm{Me}\right), 4.46(1 \mathrm{H}, \mathrm{br} \mathrm{s}, 22-$ $\mathrm{H}), 4.78(1 \mathrm{H}$, br s, 22-H), $5.29(1 \mathrm{H}, \mathrm{d}, J=9.6 \mathrm{~Hz}, 7-\mathrm{H}), 5.51(1 \mathrm{H}, \mathrm{dd}$, $J=11.4,9.6 \mathrm{~Hz}, 6-\mathrm{H}), 7.52(4 \mathrm{H}, \mathrm{br} \mathrm{d}, J=8.2 \mathrm{~Hz}$, aromatic protons), $7.84(4 \mathrm{H}$, br d, $J=8.2 \mathrm{~Hz}$, aromatic protons).

Acknowledgements We are grateful to Dr. H. Kasai and Miss N. Kobayashi of Hoshi University for the NMR and mass measurements. We also thank to Mrs. S. Saito for the elemental analyses. This study was supported in part by a Hoshi University Science/Technology Frontier Research Base from the Ministry of Education, Culture, Sports, Science, and Technology, Japan and by the Cooperative Research Program of the Research Center for Pathogenic Fungi and Microbial Toxicoses, Chiba University (04-23).

\section{References and Notes}

1) Georgopapadakou N. H., Walsh T. J., Antimicrob. Agents Chemother, 40, 279-291 (1996).

2) Harada N., Nakanishi K., "Circular Dichroic Spectroscopy. Exiton Coupling in Organic Stereochemistry," (Jpn. Ed.) Tokyo Kagaku Doujin, Tokyo, 1982, pp. 1-23.

3) McIntyre C. R., Scott F. E., Simpson T. J., Trimble L. A., Vederas J. C., Tetrahedron, 45, 2307-2321 (1989).

4) Kosemura S., Miyata H., Yamamura S., Albone K., Simpson T. J., J. Chem. Soc., Perkin Trans. 1, 1994, 135-139 (1994).

5) Springer J. P., Dorner J. W., Cole R. J., Cox R. H., J. Org. Chem., 44, 4852- 4854 (1979).

6) Kosemura S., Matsunaga K., Kubota M., Ohba S., Tetrahedron Lett., 32, 3543-3546 (1991).

7) Shiomi K., Uchida R., Inokoshi J., Tanaka H., Iwai Y., Omura S., Tetrahedron Lett., 37, 1265-1268 (1996).

8) Uchida R., Shiomi K., Inokoshi J., Sunakuza T., Tanaka H., Iwai Y., Takayanagi H., Omura S., J. Antibiot., 49, 418- 424 (1996).

9) Kosemura S., Tetrahedon Lett., 43, 1253-1256 (2002). 